\title{
Difficulty of Science and Biology Teachers to Teach Entomology in Elementary and High Schools in the State of Pará, Northern Brazil
}

\author{
Reinaldo Lucas Cajaiba* \\ Environmental Secretary - SEMMA/Uruará-PA, Brazil \\ *Corresponding author: reinaldocajaiba@hotmail.com
}

Received March 21, 2014; Revised May 14, 2014; Accepted June 05, 2014

\begin{abstract}
This study aimed to determine the main difficulties encountered by teachers of science and biology, on the teaching of the insects in public schools in three municipalities in the State of Pará. Most teachers pointed out how difficult the overcrowding of classrooms, lack of laboratories and materials for fieldwork, students ' disinterest by theme and lack of content mastery. The main teaching medium adopted by professors is the book, using data show projector and educational videos. They do not make use of practical classes to work the theme. Relative to the themes worked in the classroom were cited, the external morphology of insects, ecological importance and forms of reproduction. Hence the need to adopt a differentiated pedagogical practice in teaching Entomology, such as field trips, practical classes, didactic models and educational games among others.
\end{abstract}

Keywords: education, insects, didactic resources, entomology, teaching-learning

Cite This Article: Reinaldo Lucas Cajaiba, "Difficulty of Science and Biology Teachers to Teach Entomology in Elementary and High Schools in the State of Pará, Northern Brazil.” American Journal of Educational Research, vol. 2, no. 6 (2014): 389-392. doi: 10.12691/education-2-6-10.

\section{Introduction}

Entomology is the science that studies the insects in its most varied aspects and all its relations with the plants, with the man and other animals. Constitute the dominant group of animals on Earth, surpassing in number all other terrestrial animals, and can be found practically everywhere [1]. Are invertebrate animals with chitinous exoskeleton, body divided into three parts (head, thorax and abdomen), three pairs of jointed legs, compound eyes and two antennae. Belong to the class Insecta, the largest and most distributed group of animals belong with the phylum Arthropoda [2,3].

The study of insects is part of the content treated in various disciplines in the curriculum of elementary school, high school and university courses. We should study them for several reasons. Their ecologies are incredibly varied, are important in food chains, species richness and by affect the society in various ways, either as urban or agricultural pests (ants, worms, cockroaches, mosquitoes and disease vectors), either by using the products generated (silk, honey) or its environmental services (pollination, seed dispersal, population control of other invertebrates) [4]. Furthermore, insects serve as model in areas of evolution, ecology, behavior, anatomy, physiology, biochemical and genetics $[3,5,6]$.

Even with vast biological diversity and popularity, several people, including in this group the primary and secondary school students, think that harmful or dangerous animals are grouped in the class of insects, and confuse spiders, centipedes and ticks, along with examples of more distant classes with insects [7].

Working with the insects in the classroom brings not only the opportunity to end this prejudice, but also the possibility to use them as a teaching tool for the development of skills such as observation, argument, criticism, curiosity, creativity and clarity of expression, so desirables in the school environment [8]. Direct contact with the insects allows a freer attitude of students and at the same time occasionally favor rapprochement with the teacher.

Despite its abundance and importance, the study of insects is little discussed in the elementary and secondary education. Baptista \& Costa-Neto [21] question why the insects are no longer actively present in the classrooms, since many basic concepts can be teach through observation of insects and suggest that it is an interesting tool for elementary and high school education.

The present work aims to check what are the major difficulties encountered by teachers of science and Biology to work the contents about the insects.

\section{Materials and Methods}

The research was developed in 10 public schools in the urban areas of the municipalities of Uruará, Placas and Medicilândia in the State of Pará in northern Brazil (Figure 1). 


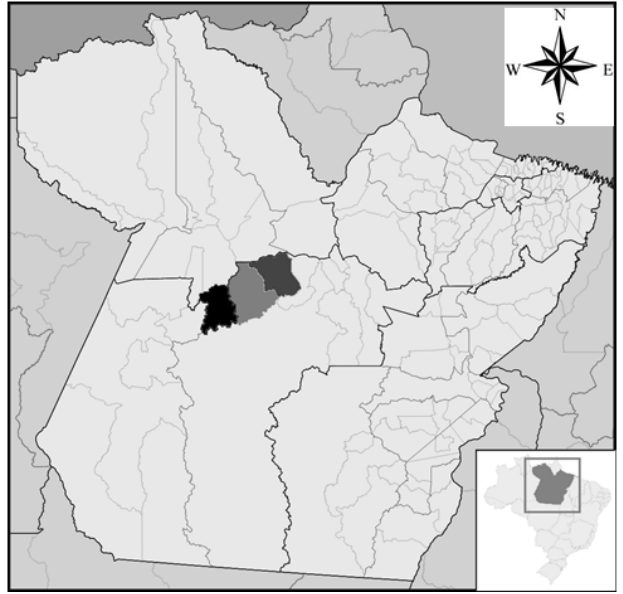

Figure 1. Location of the studied municipalities in the State of Pará (from left to right, Placas, Uruará and Medicilândia)

The research had the target public the professors of Sciences of elementary school and Biology of high school, being developed in the months of September and October 2013.

The aim was to characterize the profile of teachers through questions, such as age, academic training (complete higher education or not, with or without postgraduate), teaching time, among others. Were also verified educational resources used by teachers, such as: teaching materials used (practical lessons, field trips, didactic models, audiovisual resources, sources of research, among others).

The analysis of the data was obtained through descriptive statistics from the frequencies of variables, with the presentation of the results in percentages as tables and graphs.

\section{Results and Discussion}

Participated in the research: 57 teachers, of these, 45 teach sciences and 12 teach biology. The profile of the teachers surveyed reveals a predominance of women (80\%). Most of the teachers (63\%) have completed higher education and $8 \%$ have graduate studies (lato sensu). It was observed that $37 \%$ of teachers have less than 30 years of age and $45 \%$ between 31 and 45 years. As for the time of teaching, more than half (52\%) have between 10 and 15 years of experience, $20 \%$ less than five years and $28 \%$ more than 15 . Of the 57 teachers participating in the survey, $48 \%$ divide their time in more than one school, $12 \%$ work with other disciplines such as Mathematics, Geography, Physics and Chemistry.

Asked about the methodology used to work on insects in the classroom, most elementary school teachers (65\%) $25 \%$ cited that it uses only the textbook, $25 \%$ uses datashow, $5 \%$ say that lead the students to the library and 5\% uses educational videos (documentaries) (Figure 2A). In high school, $45 \%$ of teachers use only textbooks, $40 \%$ uses data-show, $10 \%$ uses educational videos and $5 \%$ uses cutouts from magazines (Figure 2B). In none of the three municipalities surveyed the teachers use field classes, laboratory, or any other methodology to work the theme with the students, that is, the teachers use the same methodology in all schools studied, prioritizing the use of books, Blackboard and chalk.

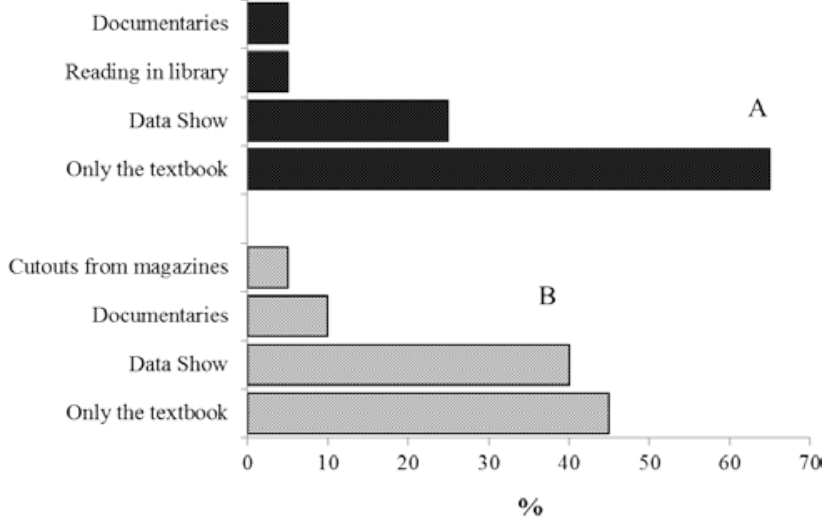

Figure 2. Methodology used by teachers to work the entomology (A) in the elementary school and (B) in the high school

The students of elementary and high of the network of public education, found usually methodologies that do not always promote the effective construction of his knowledge [9]. As shown in Figure 2, most of the teachers, both in elementary like in the high school, prioritizes the book as didactic resource, perhaps for lack of infrastructure resources in schools. The testimony of a teacher who teaches Science in elementary school exemplifies the lack of these resources at school. According to her "the school doesn't have a computer. When we want to present a theme, we have to bring our own. Furthermore, the classrooms are not ideal for displaying images via data show, because the windows are of grid, hurting the quality of images" (science teacher).

According Dourado [10] the use of audiovisual resources in the school environment is a way to facilitate the construction of knowledge both in teaching Science and Biology as with other disciplines. The audiovisual activity, beyond didactic complement, at certain times can serve as a tool for the implementation of activities that empower students through images, uncovering and clarifying doubts which often do not appear in the structure of a written text [11]

Relative to practical lessons Krasilchik [12] affirms that, although it is of fundamental importance and widely recognized, in reality they form a very small parcel in the course of science and biology, whether by lack of equipment, inadequate facilities or for the lack of time of the teachers for planning the activities [11]. For Sato \& Magalhães Jr [13], experimentation in science class is a factor of extreme importance in the teaching-learning process, because helps teachers during the classes and the students in understanding the content.

The use of differentiated pedagogical practices (e.g. educational models, field trips, classes, etc) regarding the teaching of Entomology has been very relevant, because it allows students to build knowledge about the object of study and not only receive theoretical information about the subject $[14,15]$. On this subject, Abou-Saab \& Godoy [16], is noted that the use of practices and demonstrations are essential for a more effective learning, because the life is not studied in books.

Krasilchik [17] assumes critical standpoint against this situation, stating that the teacher, by lack of selfconfidence, preparation, or for convenience, restricts itself to introduce students with minimal modification, the material previously prepared by authors who are accepted as experts. Based on material developed by others and 
produced industrially, the teacher gives up its own autonomy and freedom, becoming simply a technician [9].

According to Matos et al. [18] a discipline cannot be developed just of theoretical form, should be based on a set of practical lessons that contribute to improve the knowledge. However, in most schools are observed a shortage of biological material for conducting practical lessons. Matos et al. [18] suggest the use of teaching materials created by the students themselves. According to the authors, it is possible to use alternative materials as a demonstrative resource, making the teaching-learning process more effective and interesting with a reduced cost.

When asked about what are the main themes that are addressed in the classroom about entomology, 70\% of elementary school teachers have cited that work superficially about the ecological importance of invertebrates in general, not going into details about the insects, 20\% working the external morphology and 10\% the general characteristics of invertebrates. While in high school, $45 \%$ of teachers have cited that they work about ecological importance of insects, 30\% about the external morphology and $20 \%$ work superficially on the taxonomic classification (Figure 3).

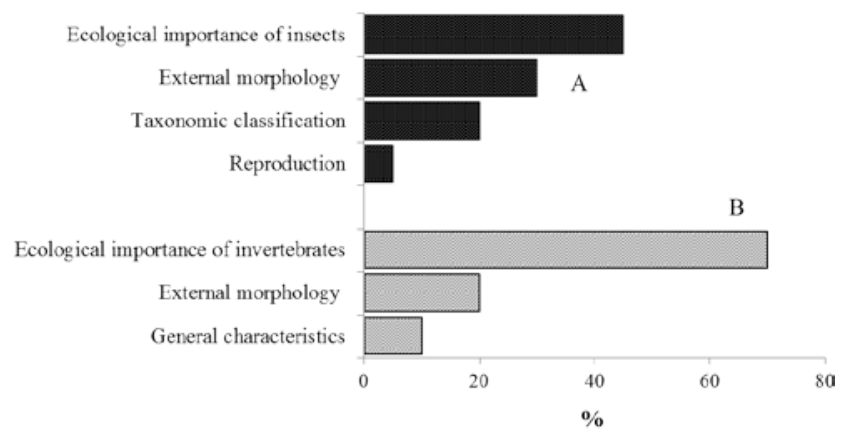

Figure 3. Main themes worked by teachers in the classroom about the insects. (A) Science and (B) Biology

The insects have a great importance for the ecosystem and we cannot sum up the content of Entomology only on the external morphology of insects or on its way of reproduction. In fact, is extensive the curriculum of science and biology, the scientific terms are difficult, the diversity of insects is enormous, so, uses only textbooks to make science and biology classes is boring and uninviting.

According to Nascimento \& Alvetti [19], the science education is vital because through it becomes possible the understanding of the phenomena of nature. However, when he asks students what it means to study science, the majority remembers the memorization of those "difficult names". This reality is confirmed when working inappropriately, reducing learning to the simple memorization of some names, what prevents the student to understand the biological processes and what this represents [20].

According to Batista \& Costa-Neto [21] often, the teaching about insects in science and biology are not conducted properly due to attitudes, instructions and experiences both the teachers and students. In the natural world, the insects (and other arthropods and some invertebrates) that more we perceive are associated with discomfort and danger. Such an attitude is frequently transmitted by the media, which teaches us that these organisms are dangerous, disgusting, disease-causing and harmful to plantations.
Given the above, it is essential that the teachers can choose literary resources dealing with the insects, contemplating the socio-cultural reality of students, making a counterpoint between the scientific and didactic contexts [8].

When asked what the greatest difficulty in work the topic, $30 \%$ of teachers have cited that the students have a great difficulty in learning taxonomic classification, 20\% say that the students do not have interest in the theme, $20 \%$ reported a lack of multimedia equipment (Tv, DVD, Data Show, computer) and 20\% cited that does not have dominion over the subject (Figure 4A). In high school most of the teachers (35\%) cited that the students have a great difficulty in learning the scientific terms, 20\% reported that the overcrowded classrooms hinders the development of methodologies and 15\% reported that do not have domain of Zoology (Figure 4B).

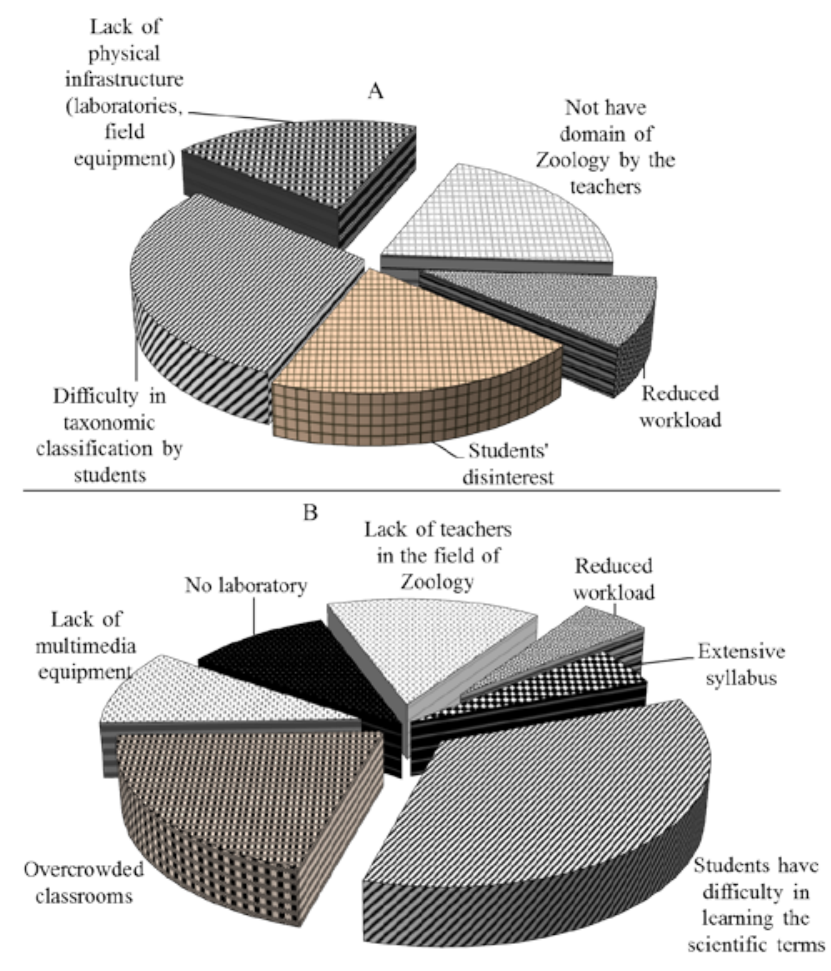

Figure 4. Main difficulties encountered by teachers to work entomology. (A) Elementary School (B) High School

When studying entomology out of context of the students, or when the teachers just teach the content of the books, it becomes boring. The lack of preparation of teachers, in addition to the extensive contents of Zoology and the reduced hourly load, both in elementary as the high school, means that most teachers do not address efficiently the content. These obstacles make that the laboratory and practical classes are increasingly more distant. Another factor that may lead this lag of the methodologies adopted by teachers can be a result of the shortcomings found in the teacher training courses which, for the most part, not be demonstrate the simplistic idea of being a teacher [22]. The ignorance of certain topics of Zoology/Entomology, has led the teachers to do not teach.

The use of insects in science class contributes to reduce repulsive characteristics associated with these organisms, since they are remembered frequently only as beings that cause disease or other damage [23]. Search for apply pedagogical practices accompanied with conceptual 
practices become a tax challenge to professor [24]. It is necessary to relate the concepts to reality of the student, giving meaning and importance to the topic presented. According to Lima \& Vasconcelos [9], such a challenge requires the integration of disciplines, expertise and qualifications, as abilities, skills, attitudes and values.

On the subject, Dourado [10] claims that the lab work and field work, within the framework of education in Sciences, are taken as important didactic resources. For Bueno \& Kovaliczn [25], theory and practice go together in science education, as well as the scientific knowledge and common sense. The use of classes with experiments is a good strategy in teaching/learning, but the realization of these practices in the classroom must be related to a student's reality.

However, the difficulties of teachers do not refer only the practical lessons and your relationship with daily life, other factors such as indiscipline of pupils, the school's physical structure, among others, are part of the difficulties encountered [26]. According to Lima \& Vasconcelos [9], factors such as overcrowding in classrooms, devaluation of the professional of education, physical structure obsolete in the school, methodology and didactics of the teachers, but also, family problems, limitation in access to textbooks and other research sources interfere in the construction of knowledge.

\section{Conclusion}

The survey conducted among the 57 teachers allows us to conclude that the most widely used didactic material is the book, followed by using Data Show and educational videos. Despite the importance of the study of insects, it is worked so shallow, and the main justification of the teachers is the overcrowding of classrooms, lack of knowledge about the topic, students ' disinterest, lack of laboratory and field equipment. The main themes worked in the classroom are summarized to the ecological importance of insects, external morphology and reproduction.

We believe that to succeed in learning of the students would be necessary to implement a differentiated pedagogical practice, promoting the attendance to the different needs of the students and linking the topic to their everyday life.

\section{References}

[1] Cajaiba RL. Introduction to Entomology. VirtualBooks Editora, 2013, 96p.

[2] Storer TI, Usinger RL, Stebbinss RC \& Nybakken JW. General Zoology. 3. ed. Companhia Editora Nacional, 1997.

[3] Leal D, Oliveira EP, Silva JK, Bosso MK, Batista WSDC, Böhm FMLZ \& Neves GYS. Production and distribution of didatic pedagogical material on insects in elementary school. Diálogos \& Saberes, 7 (1): 99-107, 2011.

[4] Borror DJ \& Delong DM. Introduction to the Study of Insects. São Paulo: Edgard Blücher, 1988.
[5] Gullan PJ \& Cranston PS. The insects: An overview of Entomology. 3. ed. São Paulo: Rocca, 2008.

[6] Andrade RC, Mateus MAF \& Proença ICL. The importance of insects in the environment: A case study along the Logosófica School Lavras, Minas Gerais. 2010. Available in: $<$ http://www.proec.ufla.br>. [Accessed in: 15 out. 2013].

[7] Macêdo MV, Flinte V \& Grenhas V. Insects in Education. V. 1. Rio de Janeiro: Fundação CECIERJ, 2005.

[8] Lage VC, Pompilho WM \& Silva FS. The importance of didatic books in the teaching of insects. Revista Práxis, 5 (7): 37-42, 2012

[9] Lima KEC \& Vasconcelos SD. Analysis of science teaching methodology used by teachers from public schools in Recife, Brazil. Ensaio: Avaliação e Políticas Públicas em Educação, 14 (52): 397-412, 2006.

[10] Dourado L. Natural science teachers' conceptions and practices on integrated implementation of laboratory work and fieldwork. Revista Electrónica de Enseñanza de las Ciencias, 5 (1): 92-212, 2006.

[11] Braga PET \& Araújo ACM. School teacher's concept regarding the study of insects at public high school level in north western Ceará, Brazil. Revista Homem, Espaço e Tempo, 1 (1): 1-15, 2012.

[12] Krasilchik, M. Practices in biology teaching. São Paulo: EDUSP, 2004. 200 p.

[13] Sato L \& Magalhães Jr, CAO. Investigation of the science teachers' difficulties according to the teaching practice through the experiment. EDUCERE, Revista da Educação, 6 (1): 35-47, 2006.

[14] Matos CHC, Oliveira CRF, Santos MPF \& Ferraz CS. Use of Didactic Models in Entomology Teaching. Revista de Biologia e Ciências da Terra, 9 (1) 19-23, 2009.

[15] Braga PET, Araújo ACM \& Cid MPC. Teaching of insects in view of brazilian and portuguese teachers. Essentia, Sobral, 13(2) 95113, 2012.

[16] Abou-Saab LA \& Godoy MT. Experimentation in the classes of biology and the appropriation of the knowledge. 2009. Available in: <http://www.diaadiaeducacao.pr.gov.br/por-tals/pde/arquivos /4464.pdf ?PHPSESSID =2009050708092673>. [Accessed em: 14 nov. 2013].

[17] Krasilchik M. Practice teaching biology. 4. ed. São Paulo: Ed. da USP, p. 198, 2004.

[18] Matos CHC, Oliveira CRF, Santos MPF \& Ferraz CS. Use of didactic models in entomology teaching. Revista de Biologia $e$ Ciências da Terra, 9 (1): 19-23, 2009.

[19] Nascimento TG \& Alvetti MAS. Contemporary issues in science teaching of biology and physics. Ciência e ensino, 1(1): 29-39, 2006.

[20] Xavier, M. Viruses and bacteria - “Small Animals”? Concept Maps and meaningful learning of the content related to viruses and bacteria in high school.. Dissertação (Mestrado em Educação e Formação de professores) Universidade Católica Dom Bosco, Campo Grande, 2000.

[21] Batista GCS \& Costa-Neto EM. Knowing the insects in school. Disponível em: <http//:www.mundoacademico.unifap.br.>. [Accessed em: 15 jan. 2014].

[22] Gil-Pérez D \& Carvalho AMP. Training of science teachers: trends and innovations. São Paulo: Cortez, 1993.

[23] Costa-Neto EM \& Pacheco JM. The construction of the ethnozoological dominion "insect" by the inhabitants of the village of Pedra Branca, Santa Terezinha, Bahia state, Brazil. Acta Scientiarum. Biological Sciences, 26 (1): 81-90, 2004.

[24] Santos DCJ \& Souto LS. Insect collection as an alternative teaching method in primary schools. Scientia Plena, 7 (1): 1-8, 2011.

[25] Bueno RSM \& Kovaliczn RA. The teaching of science and the difficulties with the experimental activities. Available in: $<$ http://www.diaadiaeducacao.pr.gov.br/portals/pde/arquivos/234.pdf $>$. [Accessed em 10 de dez. de 2013].

[26] Costa LFS, Lima KA, Andrade MGS, Barcelos MWS \& Vieira TS. Key challenges for teaching science. In: Congresso Norte e Nordeste de Pesquisa e Inovação, VII, Connepi. Palmas, TO, 2012, p. 1-8. 